\title{
Pemanfaatan Limbah Kelapa Sawit (Solid) sebagai Substitusi Jagung dalam Ransum Ayam Merawang
}

\author{
Zul Efendi ${ }^{1 *}$, Erpan Ramon ${ }^{1}$, Wahyuni A. Wulandari ${ }^{1}$, Yudi Sastro ${ }^{1}$ dan Nurhaita ${ }^{2}$ \\ ${ }^{1}$ Peneliti Balai Pengkajian Teknologi Pertanian Bengkulu \\ ${ }^{2}$ Dosen Universitas Muhammadiyah Bengkulu, jl. Irian km 6,5 Bengkulu \\ *Penulis korespondensi: zulefendi@yahoo.com
}

Artikel ini diterima (received): 22 Agustus 2020; dinyatakan disetujui (accepted): 28 Oktober 2020; terbit (published): 27 November 2020. Artikel ini dipublikasi secara daring pada https://ejournal.unib.ac.id/index.php/buletin_pt/index

\begin{abstract}
Abstrak
Penelitian ini Penelitian dilaksanakan di kandang ternak Balai Pengkajian Teknologi Pertanian Bengkulu pada Bulan Agustus - Desember 2018. Penelitian ini bertujuan untuk mengevaluasi pengaruh pemberian limbah kelapa sawit (solid) fermentasi didalam pakan terhadap performan ayam Merawang pada masa pertumbuhan (2-4 bulan). Rancangan yang digunakan adalah Rancangan Acak Lengkap dengan empat perlakuan dan lima ulangan. Sebagai perlakuan pertama (p1): dedak padi $40 \%$, jagung giling $40 \%$ dan konsentrat $20 \%$, perlakuan kedua (p2): dedak padi $40 \%$, jagung giling $37,5 \%$, konsentrat $20 \%$ dan solid $2,5 \%$, perlakuan ketiga (p3): dedak padi $40 \%$, jagung giling $35,0 \%$, konsentrat $20 \%$ dan solid $5 \%$, perlakuan keempat (p4): dedak padi $40 \%$, jagung giling $32,5 \%$, konsentrat $20 \%$ dan solid 7,5\%. Ayam yang digunakan adalah ayam Merawang berumur 2 bulan sebanyak 100 ekor, setiap perlakuan terdapat sebanyak 25 ekor. Hasil penelitian menunjukkan bahwa penggunaan limbah solid berpengaruh tidak nyata $(p>0,05)$ terhadap performan ayam kampung (Merawang) pada masa pertumbuhan. Limbah kelapa sawit berupa solid fermentasi dapat digunakan dalam ransum ayam kampung (Merawang) pada periode umur $2 \mathrm{~s} / \mathrm{d} 4$ bulan sebagai pengganti jagung giling sampai $7,5 \%$ di dalam ransum tanpa mempengaruhi performan ayam Merawang.
\end{abstract}

Kata kunci: limbah kelapa sawit (solid), ransum, ayam Merawang

\section{Pendahuluan}

Ayam Merawang merupakan salah satu dari 32 rumpun ayam lokal (ecotype) Indonesia yang berasal spesies Gallus-gallus, famili Phasianidae (Nataamijaya 2010). Jenis ayam ini pertama kali dibawa oleh penambang timah dari daratan Cina ke Indonesia pada masa penjajahan Belanda sekitar 300 tahun lalu sehingga sudah beradaptasi menjadi ayam lokal yang berasal dari Desa Merawang Kecamatan Merawang Kabupaten Bangka, Provinsi Kepulauan Bangka Belitung.

Ayam merawang merupakan sumber genetik serta aset Provinsi Kepulauan Bangka Belitung yang sangat potensial untuk dikembangbiakkan baik dalam skala kecil ataupun komersial karena memiliki keunggulan dalam produksi telur dan kandungan lemak yang rendah. Ayam Merawang umumnya dipelihara secara ekstensif (tradisionil) sehingga perkawinan silang dengan ayam kampung biasa tidak dapat dihindari. Ini mengakibatkan kemurnian ayam Merawang semakin rendah dan diduga populasinya semakin menurun. Oleh karena itu diperlukan intensifikasi teknologi budidaya. Namun, permasalahan utama yang dihadapi oleh peternak adalah besarnya biaya pakan. Biaya pakan dalam usaha peternakan ayam secara intensif mencapai $60-70 \%$ dari total baiaya yang dikeluarkan oleh peternak untuk usaha peternakannya. 
Disamping itu, bahan penyusun pakan seringkali sulit diperoleh disekitar lokasi sehingga peternak mengalami kendala dalam meracik ransum pakan yang lebih murah. Oleh karena itu, salah satu cara yang dapat dilakukan dalam menyusun ransum pakan adalah dengan memanfaatkan potensi limbah industri pertanian.

Peternak yang hidup di lingkungan pertanian berpotensi memanfaatkan sumbersumber bahan pakan yang layak digunakan dari limbah pertanian. Keunggulan limbah pertanian adalah tidak bersaing dengan kebutuhan manusia, harga murah dan tidak berbahaya bagi ternak yang mengkonsumsinya.

Lumpur sawit/solid merupakan salah satu jenis limbah pertanian yang dihasilkan dari proses produksi pabrik pengolahan minyak sawit yang dapat dimanfaatkan sebagai penyusun ransum pakan ternak. Menurut Hidayat et al., (2007) solid cukup potensial dimanfaatkan sebagai pakan ternak karena murah dan tersedia dalam jumlah besar sepanjang tahun. Sinurat et al, (2004) menyatakan bahwa kandungan protein kasar solid kering 9,6\%-14,52\% yang setara dengan kandungan protein kasar dedak padi, yaitu $13,3 \%$, dan kandungan lemak kasarnya juga relatif tinggi $10,4 \%$ dengan .nilai Total Digestible Nutrient sebesar $74 \%$, lebih tinggi dibandingkan dedak padi yang hanya $70 \%$ (Agustin et al., 1991).

Solid bisa digunakan sabagai salah satu bahan konsentrat pakan ruminansia dan unggas sebagaimana penelitian Syartoni (2008), Winardi (2008), Zueni (2008), dan Bintang et al (2003). Hasil-hasil penelitian tersebut secara umum menunjukkan bahwa penggunaan solid sebagai bahan konsentrat pakan mampu meningkatkan produksi ternak terutama pada ternak ruminansia besar. Namun belum ada penelitian tentang pengaruh penggunaan solid fermentasi terhadap performan ternak unggas. Padahal proses fermentasi dapat meningkatkan kandunganprotein kasar pada bahan pakan yang lebih baik untuk pertumbuhan unggas. Oleh karena itu penelitian ini bertujuan untuk mengetahui pengaruh pemberian solid sebagai substusi jagung terhadap performan ayam Merawang pada masa pertumbuhan (umur 2 -
4 bulan) dan penghematan biaya pakan yang diperoleh dari hasil substitusi tersebut.

\section{Bahan dan Metode}

Penelitian ini dilaksanakan dari bulan Agustus sampai dengan Desember 2018 di kandang Balai Pengkajian Teknologi Pertanian Bengkulu. Penelitian menggunakan 100 ekor anak ayam Merawang berumur 1 bulan. Ayam dibagi dalam 4 kelompok (1 kelompok terdiri dari 25 ekor) yang ditempatkan dalam kandang berukuran $2,5 \times 3 \mathrm{~m}$. Setiap unit kandang dilengkapi dengan tempat makan dan tempat minum.

Rancangan yang digunakan adalah Rancangan Acak Lengkap dengan 4 perlakuan ransum yang mengandung solid fermentasi masing-masing $0 \%, 2,5 \%, 5,0 \%$ dan $7,5 \%$ dengan 5 ulangan. Solid fermentasi dihasilkan dengan cara: bahan yang digunakan adalah Solid 1 ton, aktivator 1 liter, garam $5 \mathrm{~kg}$, urea $5 \mathrm{~kg}$, kapur $5 \mathrm{~kg}$, mollases $5 \mathrm{~kg}$ dan air 20 liter. Cara membuatnya larutkan garam, urea kedalam 20 liter air, kemudian solid di amparkan diatas terpal setinggi $+20 \mathrm{~cm}$ hingga rata, taburkan kapur diatas amparan solid hingga rata, setelah itu dilanjutkan dengan menyiramkan larutan yang terdiri dari garam dan urea tadi hingga merata semua permukaan solid, lakukan pengadukan solid dengan cara menginjak-injak solid hingga bahan tercampur dengan baik, setelah solid tercampur dengan baik, maka dilakukan pengemasan kedalam gentong plastik/plastik besar dan ditutup/diikat dengan rapat, simpan solid ditempat yang sejuk dan tidak terkena sinar matahari langsung, setelah proses berlangsung selama 1 minggu, fermentasi solid sudah selesai dan dapat diberikan kepada ternak.

Pakan diberikan sebanyak 2 kali sehari selama penelitian sesuai dengan kebutuhan pakan ayam buras, sedangkan air minum diberikan secara adlibitum. Komposisi ransum dan kandungan gizi tiap perlakuan terlihat pada Tabel 1.

Peubah yang diamati dalam penelitian ini meliputi pertambahan bobot badan, konversi pakan dan persentase karkas. Pertambahan bobot badan ayam (gram) diukur setiap minggu dengan cara mengurangkan bobot badan pada saat pengukuran dengan bobot badan minggu sebelumnya. Konsumsi pakan 
dihitung setiap minggu dengan cara mengurangi jumlah ransum yang diberikan dengan jumlah ransum yang tidak dikonsumsi dalam satuan gram/ekor. Konversi pakan diperoleh dengan cara membandingkan jumlah ransum yang dikonsumsi setiap minggu dengan pertambahan bobot badan yang dihasilkan. Persentase karkas dihitung dengan membandingkan antara bobot badan ayam setelah dipotong dan dibersihkan serta dipisahkan kaki, kepala dan jeroannya dengan bobot potong (bobot ayam yang sudah dipotong). Data yang diperoleh dianalisis dengan menggunakan analisis sidik ragam (Anova), jika terdapat perbedaan yang nyata antar perlakuan maka dilanjutkan dengan uji jarak Duncan (Steel dan Torrie, 1989).

Tabel 1. Komposisi dan kandungan gizi ransum perlakuan

\begin{tabular}{lcccc}
\hline \multicolumn{1}{c}{ Bahan Makanan } & \multicolumn{3}{c}{ Perlakuan } & P4 \\
\cline { 2 - 5 } & $\mathrm{P} 1$ & $\mathrm{P} 2$ & $\mathrm{P} 3$ & 40 \\
\hline Dedak Padi (\%) & 40 & 40 & 40 & 32,5 \\
Jagung Giling (\%) & 40 & 37,5 & 35,0 & 20 \\
Konsentrat (\%) & 20 & 20 & 20 & 7,5 \\
Solid fermentasi (\%) & 0 & 2,5 & 5,0 & 100 \\
Jumlah & 100 & 100 & 100 & 12,85 \\
\hline & & & Kandungan gizi & 1,78 \\
\hline Protein Kasar (\%)* & 13,20 & 12,35 & 13,50 & 12,14 \\
Lemak Kasar (\%)* & 2,05 & 1,73 & 1,36 & 11,90 \\
Serat Kasar (\%)* & 9,23 & 9,50 & 10,65 & 1,62 \\
Abu (\%)* & 11,29 & 11,31 & 11,97 & 0,55 \\
Kalsium (Ca) (\%)* & 1,52 & 1,64 & 1,46 & 3394 \\
Phospor (P) (\%)* & 0,56 & 0,58 & 0,60 & 3406 \\
EM (kkal/kg) * & 3460 & 3428 & 340 \\
\hline
\end{tabular}

Keterangan : *Hasil analisis proksimat pada Balai Penelitian Ternak Ciawi, Bogor 2017.

\section{Hasil dan Pembahasan}

\section{Pertambahan bobot badan}

Rataan bobot badan akhir ayam merawang yang dihasilkan selama penelitian berkisar antara 1.290 - 1.470 gram/ekor. Oleh karena itu, ayam Merawang umur 2-4 bulan dapat diberikan ransum yang mengandung solid fermentasi dengan level $7,5 \%$ sebagai pengganti jagung giling

Bobot badan sangat erat kaitannya dengan tingkat konsumsi dan pertambahan bobot badan seekor ternak. Menurut Wahyu (1977) dalam Yunilas et al. (2006), tingkat konsumsi ransum banyak ditentukan oleh palatabilitas ransum, sistem tempat pakan dan pemberian pakan serta kepadatan kandang.

Walaupun bobot badan pada akhir penelitian bervariasi, tetapi setelah dilakukan analisis keragam ternyata tidak menunjukkan perbedaan yang nyata pada setiap perlakuan. Oleh karena itu dapat diartikan bahwa ayam merawang dapat diberikan ransum yang mengandung solid fermentasi sampai dengan level 7,5\% sebagai pengganti jagung giling.

\section{Konsumsi pakan}

Performan seekor ternak dapat dilihat dari konsumsi pakan, konversi pakan dan produksinya (Sukarini dan Rifai, 2011). Dari Faktor -faktor yang mempengaruhi performan produksi, ternyata faktor pakan yang paling berpengaruh. Konsumsi pakan merupakan cermin dari masuknya sejumlah unsure nutrient ke dalam tubuh ayam (Rasyaf, 2008). Pemberian solid decanter yang difermentasi sebagai pengganti jagung giling dalam ransum sampai level $7,5 \%$ tidak berpengaruh nyata terhadap konsumsi pakan ayam merawang sampai umur 4 bulan. Hal ini menunjukkan bahwa konsumsi pakan dipengaruhi oleh komposisi pakan dimana antara perlakuan $\mathrm{p} 1$, p2, p3 dan p4 tidak terdapat perbedaan yang mendasar baik bahan maupun konsentrasinya. Menurut Church (1979) menyatakan bahwa faktor yang dapat mempengaruhi konsumsi adalah palatabilitas. Palatabilitas dipengaruhi oleh bau, rasa, tekstur dan warna pakan yang diberikan. Hal senada juga diungkapkan oleh Abun (2005) yang menyatakan bahwa meningkatnya pakan yang dikonsumsi akan 
memberikan kesempatan pada tubuh untuk meretensi zat-zat makanan yang lebih banyak, kebutuhan protein zat-zat makanan yang lebih banyak, sehingga kebutuhan protein terpenuhi.

Kandungan serat kasar yang tinggi akan menyebabkan ayam cepat kenyang (bulky). Pakan yang bersifat bulky berpengaruh terhadap tembolok, dimana di dalam tembolok terjadi distensi pada saraf-sarat yang akan menghantarkan impuls ke hipotalamus agar menghentikan konsumsi ayam. Cherry (1982) menyatakan bahan serat kasar dalam ransum yang tinggi dapat menyebabkan ayam mengkonsumsi pakan dalam jumlah sedikit karena ayam merasa kenyang. Semakin tinggi serat kasar dalam ransum menyebabkan jumlah konsumsi ransum semakin menurun, karena ransum bersifat bulky sehingga ransum yang dikonsumsi terbatas. Selanjutnya Yuwana (2004) menyatakan bahwa tembolok terdapat syaraf yang berhubungan dengan pusat kenyang-lapar di hipotalamus, sehingga banyak sedikitnya pakan yang terdapat dalam tembolok akan memberikan respon terhadap syaraf untuk makan atau menghentikan makan.

\section{Konversi pakan}

Konversi pakan merupakan pembagian antara konsumsi pakan dengan pertambahan bobot badan yang dicapai pada suatu periode waktu tertentu. Bila rasio kecil berarti pertambahan bobot badan terjadi secara optimal. Pemberian solid decanter yang difermentasi sebagai pengganti jagung giling dalam ransum sampai level $7,5 \%$ tidak berpengaruh nyata terhadap konversi pakan ayam merawang sampai umur 4 bulan. Faktorfaktor yang mempengaruhi konversi pakan adalah faktor genetik, umur, berat badan, tingkat konsumsi pakan, pertambahan bobot Tabel 2. Rataan bobot badan akhir, konsumsi dan konversi pakan.

\begin{tabular}{cccc}
\hline Perlakuan & $\begin{array}{c}\text { Rataan Bobot Badan Akhir } \\
\text { (gram/ekor) }\end{array}$ & $\begin{array}{c}\text { Rataan Konsumsi Pakan } \\
\text { (gram/ekor/hari) }\end{array}$ & Konversi Pakan \\
\hline p1 & $1.470^{\mathrm{a}}$ & 5.985 & $4,07^{\mathrm{a}}$ \\
p2 & $1.300^{\mathrm{a}}$ & 5.950 & $4,57^{\mathrm{a}}$ \\
p3 & $1.350^{\mathrm{a}}$ & 5.935 & $4,39^{\mathrm{a}}$ \\
p4 & $1.290^{\mathrm{a}}$ & 5.820 & $4,51^{\mathrm{a}}$ \\
\hline
\end{tabular}

Keterangan: Angka-angka yang diikuti huruf yang sama pada kolom yang sama menunjukkan tidak berbeda nyata $(p>0,05)$ badan, palatabilitas dan hormon. Hal ini sesuai dengan pernyataan Lubis (1993) yang menyatakan bahwa konversi pakan sangat dipengaruhi oleh kondisi ternak, daya cerna, jenis kelamin, bangsa, kualitas dan kuantitas ransum dan faktor lingkungan.

Efesiensi pakan didefinisikan sebagai perbadingan jumlah unit yang dihasilkan (pertambahan bobot badan) dengan jumlah unit konsumsi pakan persatuan aktu yang sama. Semakin baik mutu pakan ternak ayam, maka semakin kecil nilai konversi pakannya. Baik atau tidak mutu pakan ditentukan oleh keseimbangan zat gizi pada ransum dengan yang dibutuhkan oleh tubuh ayam. Pakan yang kekurangan salah satu unsure gizi akan mengakibatkan ayam mengkonsumsi pakan secara berlebihan untuk mencukupi kekurangan zat yang diperlukan tubuhnya (Sarwono, 1996). Konversi pakan ayam merawang yang diberikan pakan yang mengandung solid fermentasi $0 \%-7,5 \%$ sebagai pengganti jagung giling lebih dibandingkan dengan konversi pakan ayam kampung super (umur 3-10 minggu) yaitu 5,0 $-5,5$ (Wicaksono, 2015).

\section{Persentase karkas}

Kualitas ransum merupakan salah satu faktor yang mempengaruhi bobot akhir dan persentase bobot karkas dari seekor ternak. Pemberian solid decanter yang difermentasi sebagai pengganti jagung giling dalam ransum sampai level 7,5\% tidak memberikan pengaruh yang nyata $(P>0,05)$ terhadap persentese karkas ayam merawang. Rata-rata persentase karkas ayam merawang umur 4 bulan berkisar antara 65,72 - 66,52\%. Hasil yang sama didapatkan oleh Widjaja et al. 2006 pada ayam broiler dengan bobot karkas $65,89 \%$ pada pemberian solid pada ransum sebanyak $12,5 \%$. 
Menurut Soehartono (1976) karkas yang baik harus mengandung banyak daging, hasil ikutan rendah serta lemak tidak begitu tinggi yang semuanya dipengaruhi oleh pakan dan pemeliharaan. Ransum yang dikonsumsi merupakan faktor penting yang mempengaruhi pertumbuhan dan komposisi karkas untuk mencapai bobot karkas yang diharapkan.

Tren pertambahan bobot badan ayam merawang dapat dilihat pada grafik 1 . Pada grafik 1 terlihat bahwa tren pertambahan bobot badan mingguan ayam merawang selama 2 bulan penelitian menunjukkan perkembangan yang positif pada setiap perlakuan, sehingga bobot ayam merawang pada akhir penelitian tidak menunjukkan perbedaan yang nyata.

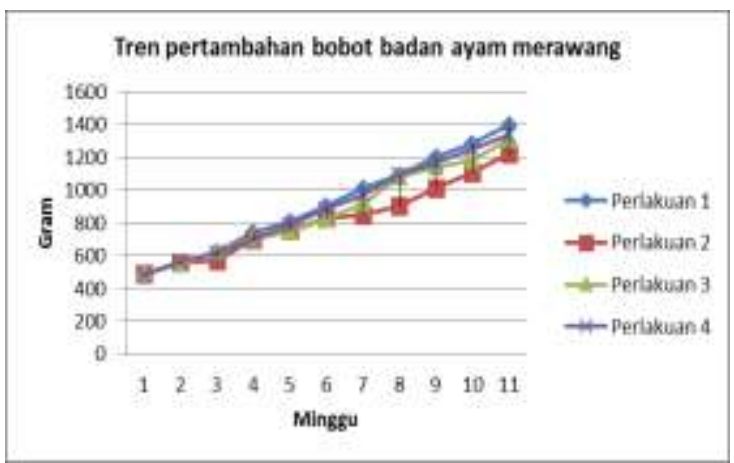

Gambar 1. Tren pertambahan bobot badan ayam merawang.

\section{Kesimpulan}

Limbah kelapa sawit berupa solid fermentasi dapat digunakan dalam ransum ayam kampung (merawang) pada periode umur $2 \mathrm{~s} / \mathrm{d}$ 4 bulan sebagai pengganti jagung giling sampai $7,5 \%$ di dalam ransum tanpa mempengaruhi performan ayam tersebut.

\section{Ucapan Terima Kasih}

Ucapan terima kasih disampaikan kepada Kepala BPTP Bengkulu yang telah memberikan arahan dan bimbingan dalam pelaksanaan penelitian ini. Kepada rekan- rekan yang telah membantu dalam pelaksanaan sampai dengan penulisan karya tulis ilmiah ini.

\section{Daftar Pustaka}

Arianto, S. 2018. Performans produksi telur ayam Arras dan ayam Arab umur 20 sampai 40 minggu. Skripsi. Jurusan
Peternakan Fakultas Pertanian Universitas Bengkulu. Bengkulu.

Abun. 2005. Efek ransum mengandung ampas umbi garut produk fermentasi oleh kapang Aspergillus niger terhadap imbangan efisiensi protein dan konversi ransum pada ayam broiler. Laporan Penelitian. Fakultas Peternakan Universitas Padjadjaran. Bandung.

Agustin, F. , Sutardi, D. Sastradipradja, dan J. Jachja. 1991. Penggunaan Lumpur Minyak Sawit Kering (Dried Palm Oil Sludge) dan serat Sawit (Palm Press fiber) Dalam Ransum Pertumbuhan Sapi Perah. Bul. Mater, 11(1); 28-29.

Bintang. I.A.K, A.P. Sinurat dan T. Purwadaria. 2003. Respon Broiler terhadap Permberian ransum yang mengandung Lumpur Sawit fermentasi pada berbagai lama penyimpanan. JITV vol. 8. No. 2:71-75.

Cherry. 1982. Turmeric (Curcuma longa) root powder and mannanoligosaccharides as alternatives to antibiotics in broiler chicken diets. J Anim Sci 16(10):14951499.

Church, D. C. 1979. Livestock Feed and Feeding. Durhan and Cowney. Inc. Portland. Oregon.

Hasnelly, Z, Rinaldi dan Suwardih. 2006. Penangkaran dan Perbibitan Ayam Merawang di

Bangka Belitung. Lokakarya Nasional. Inovasi Teknologi Dalam Mendukung Usaha Ternak Unggas Berdaya Saing. 7581.Semarang, 4 Agustus 2006.

Hidayat, Soetrisno, E., Akbarillah,T. 2007. Produksi ternak Sapi Berbasis Hasil Ikutan Kebun Sawit Melalui Peningkatan Kualitas Pakan, manipulasi Ekosistem Mikrobia Rumen Dan Protein By Pass. Laporan Penelitian Hibah Bersaing. Lembaga Penelitian Universitas Bengkulu.

Lubis, D.A, 1993. Ilmu Makanan Ternak. PT. Pembangunan. Jakarta. 
Nataamijaya, A.G. 2010. Pengembangan potensi ayam lokal untuk menunjang peningkatan kesejahteraan petani. J. Litbang Pertanian 29(4): $131-138$.

Rasyaf. 2008. Beternak Ayam Petelur. Penebar Swadaya. Jakarta.

Syarthony, H. 2008 Pengaruh Penggunaan Pelepah Sawit Segar dan Amoniasi Dengan Dua Macam Formula Blok Pakan Konsentrat Terhadap Pertambahan Berat Badan sapi. Skripsi jurusan peternakan. Universitas Bengkulu, Bengkulu (tidak dipublikasikan).

Sinurat, A. P., T.Mathius, I. W. Sitompul, D. M. dan Manurung, B. P. 2004. Intregasi Sawit-Sapi: Upaya Pemenuhan Gizi Sapi Dari Produk Samping. Prosiding Seminar Nasional: Sistem Intregasi Tanaman Ternak. Pusat Penelitian dan Pengembangan Peternakan Bekerja Sama Dengan BPTP Bali dan CropAnimal System research Network (CASREN). PP424-429.

Soehartono. 1976. "Respon Broiler Terhadap Berbagai Kondisi Lingkungan". (Disertasi). Bandung: Universitas Padjajaran Bandung.

Sukarini. N. E., dan A. Rifai. 2011. Pengaruh Penambahan Berbagai Tepung Hijauan terhadap Performans Produksi Ayam Arab. Akademi Peternakan Karanganyar. Semarang.

Wicaksono, D. 2015. Perbandingan Fertilitas, susut tetas, Daya Tetas daan Bobot Tetas Ayam Kampung pada Peternakan Kombinasi. Skripsi.
Jurusan Peternakan. Universitas Lampung.

Widjaja. E, W.G. Piliang, I. Rahayu dan B.N. Utomo. 2006. Produk samping kelapa sawit sebagai bahan pakan alternative di Kalimantan Tengah: Pengaruh Pemberian solid terhadap performan ayam broiler. Jurnal JITV Vol. 11 No. 1.

Winardy, T. 2008. Kecernaan Bahan Kering, Bahan Organik, Protein Kasar dan Energi Pakan Pelepah Sawit Segar Dan Amoniasi Yang Disuplementasikan Blok Pakan Konsentrat Berbasis Lumpur Minyak Sawit dan Bungkil Inti Sawit Pada Sapi. Skripsi Jurusan peternakan. Universitas Bengkulu, Bengkulu (tidak dipublikasikan).

Yunilas, S. Umar dan M. Rahmatsyah. 2006. Pemanfaatan solid decander fermentasi dan suplementasi minerah zincum dalam ransum terhadap karkas itik peking umur 12 minggu (utilization of solid decanter fermented and zinc's mineral suplemenation in feed on carcass of 12 weeks old peking duck). Jurnal Agribisnis Peternakan, Vol.2, No.1.

Yuwanta, T. 2004. Dasar Ternak Unggas. Kanisius. Yogyakarta.

Zueni, A. 2008. Pengaruh Penggunaan Blok Pakan Konsentrat Berbasis Lumpur Minyak Sawit yang di suplementsi Minyak Sawit Dengan Pakan Basal Pelepah Sawit Segar Terhadap Pertambahn Berat Badan Sapi Bali. Skripsi Jurusan peternakan. Universitas Bengkulu, Bengkulu. 